\title{
2 Exploring the ethics of Ubuntu in the era of COVID-19
}

\author{
Beatrice Okyere-Manu and \\ Stephen Nkansah Morgan
}

\section{Introduction}

Since the outbreak of the coronavirus disease 2019 (COVID-19), which is known to have started in the Wuhan City, Hubei province of China in December 2019, the disease has had a global spread and led to many deaths. As on 23 May 2020, the total number of infections globally was at 5,331,427 with associated 340,560 deaths (COVID-19 Coronavirus Pandemic, 2020). Egypt was the first African country to confirm a case of the coronavirus in Africa on 14th February 2020 involving a Chinese national. Since that first infection, the disease has emerged and spread throughout the continent, and the number of infections keeps rising daily to date. The total number of infections in Africa as on 23 May 2020 was 106,299 with 3,205 deaths. South Africa, at this time, has the highest number of infections at 20,125, with 397 deaths, followed by Egypt at 15,786 with 707 deaths (COVID-19 Coronavirus Pandemic, 2020).

Although, as the numbers indicate, Africa has a very low number of infections and deaths globally, the devastating effect and impact of the disease are no less felt on the African continent. Just as it is for the rest of the world, the COVID-19 pandemic has brought with it so much socio-economic hardship on the African people. It is estimated that the African continent is going to feel the economic impact the most due to its already existing poor and below-average socio-economic conditions even before the advent of the pandemic. Billionaire Bill Gates, for example, warned that the coronavirus pandemic could have more 'dramatic effect' in Africa than in China due to Africa's weak health system, which he believed may become overwhelmed (Wasserman \& Monynihan, 2020). The World Health Organization also cautioned that the coronavirus has the potential to 'smolder' in Africa for many years and bring with it a high death toll across the continent (Burke \& Akinwotu, 2020).

The ensuing governments' nationwide or partial lockdowns in affected African states and governments' regulations of social distancing, selfisolation, ban on large gatherings, closure of schools and churches, ban on funerals, and other social gatherings as measures to combat the spread of 
the virus have affected the daily lives of the African people. Considering all these restrictions, there exist the tendency for panic and the disregard for positive cultural values that have held the people together. It is purposely because of this that the authors believe that the ethics of Ubuntu can present the African people some valuable moral values that bring to bear their germaneness in the COVID-19 period. This would ensure that the African does not abandon these values that, which in no small extent, mark out their Africanness.

The significance of cultural values to a society cannot be overemphasized. Sub-Saharan Africa is known for its rich values. These identifiable prevailing norms and values are widespread across the continent, although they may be expressed quite differently from one place to another. Traditional Africa is known for its conservativeness and slowness to change. Custodians of African cultures do their very best to often pass on their beliefs and values from one generation to another in a bid to ensure the continuity and preservation of their inherited traditions, which, often, is traced to generations before them in their respective histories. Nevertheless, cultural practices, beliefs, and values, as we know them, are often born out of necessities and as attempts to grapple with social, political, economic, and environmental exigencies of the group at a particular point in time. So that as these exigencies change, one would naturally expect that the group adjust, adapt or invent new approaches and values to tackle them.

Values are, more so, regarded as the moral and social ideals of a group of people that guide their everyday behavior, including what they hold as true, good, evil, taboo, beautiful, and just. Benson Igboin considers values as "the standard which members of the community adhere to in their personal and communal interaction towards the achievement of the goals" (Igboin, 2013, p. 98). He also regards them to be that which determine members who deserve praise or admonishment for their actions. Value can, in a way, denote that which is desirable (Igboin, 2013). For Gabriel Idang (2015), values can be perceived as a set of beliefs held about what is right and wrong and what is taken to be essential in life. He regards them as a point of view or convictions that people live with or live by and can even die for. These characterizations of values show how important values are to a people and perhaps the extent at which they are willing to go to defend or keep them. Idang points out further that since values are central to every culture and culture is what gives a people an identity, it stands to mean that these values they hold are mainly those which distinguish them from others.

Ruth Bulus Iganus and Andrew Haruna note that

through modern changes in this globalized world, the African traditional setting or ways of managing crisis cannot remain intact, but they are by no means extinct. In times of crisis, they often come to surface or people revert to them in secret. 
Thus, it suffices to ask whether the African ethics of Ubuntu is robust enough to adapt and remain relevant during this COVID-19 pandemic. If it is, what moral principles therein are useful to assist Africans, and by extension, the rest of the world to navigate through this pandemic successfully? Idang (2015) believes that cultures always try to preserve values that are essential for the survival of their people. James Lassiter (2000) similarly asserts that many African scholars have many times pointed out that the use of these widely shared values, themes, and adaptive responses are vital in the attainment of feasible and sustainable African national and community development so much that some consider this effort as an important one for the crucial survival of Africa and its cultures.

The African ethics of Ubuntu has not only existed and guided the moral behavior of traditional African people but has shown itself to be relevant to modern African societies and adaptive to current socio-political challenges of the African people and beyond. As a result, the chapter aims to test the resilience of the ethics of Ubuntu in the face of the COVID-19 pandemic. By so doing, it critically explores ways in which the African ethics of Ubuntu remains relevant in the lives of African people who are confronted with a way of life quite different from what they are used to. Ultimately, the question being asked is how the principles of Ubuntu can influence an ethical outlook that can help the African people cope, manage, and survive the COVID-19 pandemic. The work is entirely non-empirical and relies entirely on already published works in its assessments, analyses, and recommendations.

\section{The African ethics of Ubuntu}

The concept of Ubuntu is dominant in sub-Sahara communitarian Africa. This concept is also referred to as Boto, Ukama, Umundu, Bumuntu, amongst different people in Southern Africa. This singular word is embedded with such rich philosophical and metaphysical principles that have been argued to be the cultural, ethical, social, and political driving force of the African people. It does indeed embody the very identity of the African people and informs what they do, how they live, and their relationship with each other and others. It reflects their communitarian attitude, and their communitarian attitude reflects it. Barbara Nussbaum defines it as "the underlying social philosophy of African culture" (Nussbaum, 2009, p. 100), while Mogobe Ramose (2002) describes it as the root and basis of African philosophy, the wellspring flowing with African ontology and epistemology. Due to its richness in value, Ubuntu has been used in socio-political policies and theorization as well as in prescribing moral values to confront modern African challenges, and in defining the African sense of a good life. Again, due to its richness, a direct English translation of the word Ubuntu does not come readily. The closest English word commonly associated with it is humanness (Metz, 2007; Ramose, 2009) and perhaps rightly so if one should take the various related moral principles often extracted and extrapolated from it into account. 
It is the moral connotations or underpinnings of Ubuntu that define what could be termed as the ethics of Ubuntu, albeit it is not any radically different from its socio-political connotations. The ethics of Ubuntu reflects on the human relationship with others, which is a relationship that highlights the interconnectedness of all humans, and that this interconnectedness is needed for individuals' self-realization. In other words, a person is not complete without others; an important reason why Africans tend to lay more emphasis on community solidarity rather than individual personal pursuits. As a result of this unavoidable inter-human relationship, one is to pursue a moral life that enforces or lead to common accord and social harmony with others. Thus, Mluleki Munyaka and Mokgethi Motlhabi refer to Ubuntu as "a way of life that seeks to promote and manifest itself and is best realized or made evident in harmonious relations within society" (Munyaka \& Motlhabi, 2009, p. 65). To make this common accord and social harmony possible requires each person to consider the wellbeing of others in the pursuant of their wellbeing. Subsequently, to consider the wellbeing of others is also accomplished through the show of care and brotherliness/sisterliness for others and making the needs of others one's concern. In other words, a person's wellbeing is only laudable if it is linked with the overall wellbeing of the brother/sister community. In recent times, many scholars such as Mangena (2009), have critiqued term ubuntu, nevertheless, the fact still stands that its values are obtainable in the era of COVID-19.

Thus, the remainder of the chapter reflects on some of these ethical principles of Ubuntu such as the show of solidarity and good human relationship, strong regard for family and family values, and elevated respect for authorities and elders to demonstrate how the ethics of Ubuntu can inform the best ways to live and relate with each other amidst the COVID-19 pandemic.

\section{Solidarity and good human relationship}

The humanistic feature of African ethics is well known and documented. Kwame Gyekye defines it as "the doctrine that sees human needs, interests, and dignity as fundamental" (1995, p. 43). Egbunu Fidelis Eleojo (2014) understands it as an attitude which does not only elevate the overall good of the human person but also the good of the African person as the purpose of all actions. It involves a constant concern for his or her wellbeing as the central object of policy. There is a famous saying among the Akans of Ghana that onipa na ehia, which means that it is the human being that matters. The implication of this is evident; it is to say that actions, behaviors, habits, attitudes, and characters that lead to the betterment of human life and wellbeing is paramount, required, preferred, and always encouraged rather than the amassing of wealth and properties or actions that bring about human misery and pain. This should foster a sense of good human-to-human relationship among people, a relationship where there is a demonstration of care for others and not only for oneself. Macaulay Kanu (2010) asserts that 
maintaining this type of relationship between individuals shows recognition of their worth as human beings without having recognition only for what they own or what one can receive from the other in return. It is essentially a fundamental recognition of the dignity of every person regardless of their position or status in life. This ought to be considered the starting point of all other values. Kanu writes further that in these traditional African societies:

Help for one another is not based on immediate or an exact equivalent remuneration. Everyone is mindful that each person has something to contribute to his welfare, no matter the degree. The arrangement of human relation is that of being one's brother's keeper or caring for each other's welfare. Every man is obliged to assist those who need help. The needy and the helpless are taking care of and assisted.

(Kanu, 2010, p. 153)

The value of a good human relationship remains very relevant during this pandemic. Surely, as nations and regions go under either partial or full lockdown, not everyone in the society has the financial means to get involved in the panic buying that was reported all over the continent. The poor and the destitute in our societies cannot stock food and groceries, and there are many of whom the order to stay at home will be of no effect because the streets are their homes. The way we can employ this virtue to help the vulnerable among us during this pandemic is to offer them a helping hand in any way that we can, either by offering them food and other essential groceries, hand sanitizers, and teaching them to observe social distancing. We will not be exhibiting the value of good human relationship if a few of us lock ourselves in the room with all we need while the poor are left on the streets in hunger and at the mercies of the disease.

For instance, the Human Right Watch reported on May 202020 that the South African government was ignoring the plight of refugees and asylum seekers who were confined in their homes and unable to work to provide for themselves due to the pandemic. It urged the government to take crucial steps to provide needed support for refugees and asylum seekers with little access to food and other basic necessities during the nationwide lockdown (Human Rights Watch, 2020). Evidently, any act that excludes a particular group of people does not foster good inter-human relationship. Ubuntu promotes integration rather than exclusion.

Related to the above value of a good human relationship is the value of community and solidarity. African societies are communitarian, a feature that leads to a shared social way of life. As such, members of the community join efforts in the attainment of the community's good and the good of the individual members, although the latter is often submerged within the former. The community's good or interest is mostly referred to as the common good, that is, the good that is mutually beneficial to all. This communitarian attitude and social way of life are highly primarily motivated 
by the value of solidarity and community. These values of solidarity and community suggest that one must always seek the good of the larger society rather than for one's self-interests. The good of the society is that action which promotes the overall wellbeing of the community. Out of the value of communalism comes other virtues such as looking out for others, caring for others, being benevolent and altruistic, being social, interdependence, co-operation, reciprocity, and being sympathetic.

A portrayal of solidarity is the vehicle towards the display of community. At the core of a communal society is a strong expression of solidarity. Solidarity is an authentic show of concern and empathy with others and an actual manifestation of these concerns with deeds that do not have conditions attached to them except for the desire to see others do well and the desire to ensure community's progress. An important aspect of community and the show of solidarity is recognizing that one's success is not truly a success if others do not succeed as well. Solidarity is a strong ideal expressed within the principles of Ubuntu and underscores the primacy of the human person and a strong need for everyone to join their individual forces to help alleviate or ameliorate the needs and suffering of others.

Gyekye (1995) posits that in the pursuit of human wellbeing, there is a need to adequately consider the distribution of the material and social benefits of the society, the adequacy and fairness of its legal system, and social justice, equality, equitable distribution of goods, and human rights. That said, the sense of community and solidarity is best expressed during this pandemic when we work together as a community to end the spread of the coronavirus. Resultantly, there is a need to pay heed to the directives of health experts and practice social distancing, self-isolation, and staying home when we can. It is indeed one of the rare occasions where we show solidarity and community by avoiding social gatherings. This is very important in the African context because sociability as well as physical and tactile social interactions are the hallmarks of traditional African societies and tend to manifest in almost every aspect of their socio-cultural lives. This means that there is a need to find new ways of showing solidarity, a sense of community, or community participation aside mass social gatherings to observe rites of passage (naming ceremonies, puberty rites, marriage rites, and funerals), festivals, among others.

The first step in doing this is by playing our part to end the spread of the virus, although the conditions may be unusual, unfamiliar, and uncomfortable to us. It is, therefore, not consistent with the values of solidarity and community, the actions of those who defile directives to stay at home or to put themselves in self-quarantine or those who agitate against government's lockdown directives. Such acts are best described as self-centered and individualistic. These individuals do not show Ubuntu nor have the common good of the society at heart.

Secondly, the pandemic has deepened and continues to deepen the yawning gap between the rich and poor in African societies. Already existing 
inequalities have been made worse with many people losing their jobs. This means more people are going to end up with nothing to eat as the lockdown extends. Plan International, as of May 2020, tells us that more than 5.8 million people in Zimbabwe and 2 million in Mozambique have been affected by food insecurity as a result of climate change, and political and economic instability. The situation in the two countries has been made dire in the wake of the COVID-19 pandemic (Plan International, 2020). Given these unfortunate situations, the pandemic presents a great opportunity for ubuntu to go to work, a test of the African's capability to solidarize with the vulnerable in society.

So far, some have been up to the task. A couple of individuals and some cooperation and institutions have made donations of food and clothes to the poor, and Personal Protective Equipment (PPEs) for the frontline health workers and health facilities. In South Africa, for example, the government set up a fund it calls 'The Solidarity Fund' on 23 March 2020 to provide an avenue for both public and private sectors, individuals and groups to donate in support of government initiatives. The fund has received large endorsement and support from both local and international quarters. Direct Relied, a nonprofit humanitarian organization, for example donated 1 million dollars to the Fund for the purchase of PPEs. Direct Relief President and CEO Thomas Tighe, who also serves as Managing Director of Direct Relief South Africa said that, "South Africa's Solidarity Fund is exactly the type of unifying, pragmatic approach that makes sense in the face of a pandemic that threatens everyone" (Sherer, 2020).

Similarly, private firms like SPAR South Africa and SPAR Zimbabwe partnered with NGOs such as Operation Hunger, Miracle Missions, and We2ndChance, and made separate donations of assorted food items to less fortunate families in their respective countries. Workers of SPAR and individual volunteers helped with the packaging of the food items in beautiful show of solidarity. According to Brett Botten, Managing Director of the SPAR South Rand Distribution Centre: "The donation aims to inspire people to be and do more. It is during times like these that we need to work together and support each other" (SPAR South Africa, 2020). Similar donations are reported throughout the continent as a practical show of solidarity among the people.

\section{Strong regards for family and family values}

The expression of community and solidarity as well as virtues such as interdependency and concern for other people's wellbeing start at the family level. The notion of family in the traditional African context includes all members of the extended family. The family is a composition of people who share common blood or ancestry. There are, of course, many positive benefits that the individual enjoy by belonging to a family or a clan. The family, for example, gives to the individual identity, support in times of need, and a sense of 
belonging. Gyekye (1996) notes that one of the well-regarded values in traditional African societies is the social security or economic insurance that the extended family system offers. The security, he notes, covers family members who are old, poor, deprived and those struggling to make it in life despite their efforts. Wealthier and more successful members hold it as a duty to take care of the vulnerable members among them: first, for the fact that they are their blood and kin and, second, because they are the ones going to be there for them when they are also in need. The extended family system, therefore, provides a safety net where all of its members can run to when all odds fail or are against them. It is a place where members come to at any time to seek comfort and safety and recuperation from the challenges of their world. Consequently, the ethics of Ubuntu, which is altruistic and others-serving ethics, underscore the need for one to care for their family needs. Greediness and self-centeredness are actions that are frowned upon and eschewed.

While commenting on Southern African experience, Vhumani Magezi (2018) draws our attention to what he calls 'strongly enunciated rules about kin, responsibility and co-residence' that are passed down from the older generations to the younger generations. The extended family bond, Magezi maintains, is so strong that even when a member moves to work and settle elsewhere, they are expected to keep faith with the instructions, norms and values that have been handed down to them from the elders. He indicates that it is less likely for an individual to abandon who they are because they have moved to the city, for to abandon the values and norms passed on from the older generation is to deny oneself as an extension of the rural community (Magezi, 2018). Just line most Southern Africa countries, Iganus and Haruna (2017) indicate that among the Babur-Bura of Nigeria, to be considered in high esteem, one must partake in the beliefs and be involved in the cultural practices such as ceremonies, rituals, festivals of joy or suffering. As a result of these, they note that one cannot afford to exist without the family.

How then do we apply the principles in the value that Africans have for the family in the context of the COVID-19 pandemic? Here, family members need to identify the vulnerable and needy members among themselves and extend a helping hand. While the tendency for self-preservation, that is, to look within and to cater for only oneself and one's immediate family members, is high due to the loss of many jobs and reduction in income, it is here one needs to demonstrate a high moral fortitude and exhibit the spirit of Ubuntu the most by rising to the occasion. There is a need to extend a helping hand to every member of the extended family who may be faced with a job loss due to job cuts and retentions and those who may fall victim to the virus and become sick and bedridden.

Iganus and Haruna (2017) indicate that in preserving the extended family structure, some vital coping strategies used were the fellowship of sharing joy and suffering, faith and hopes. Consequently, it is crucial to bring to bear the act of sharing with others during the pandemic by caring for the sick and providing for the needy and giving family members hope when they 
are in despair. More so, the family must be there for members who may lose their lives to the pandemic and make sure that children who lose their parents or guardians to the virus are brought within their care. It is part of the African culture to show up and show solidarity when it is most needed in time of crises, and the coronavirus pandemic should not be an exception. The extended family system provides a bigger network of people who are more closely connected and can rely upon each other in these times.

\section{Elevated respect for authorities and elders}

In traditional African societies, age is very significant and not considered a mere number. The number of years one has attained is often the measurement of the level of one's experience and wisdom. Older people, are, as a result, often conferred with for advice on life choices and life challenges. They are also consulted to resolve conflicts and personal feuds and on major decisions to be taken by the family or by the community. Elders are highly respected, and it is believed that disrespecting an elder, stranger or not, is asking for curses upon one's self. On the contrary, anyone who assists an elderly receives blessings of goodwill, good health, and long life. According to Kanu (2010), the significance of the African value of respect for elders is reflected in an Igbo saying that translates in English as: 'He who listens to an elder is like one who consults an oracle'. He explains that by this, the Igbo people liken the words of the elders to that of the oracles who are held to offer indubitable and sound truths. This implies that since the elders are regarded as the leaders and authorities in the community and the repository of wisdom, adhering to their words and instructions will not lead one astray. This is because the elders, just like the oracles, are considered to always look out for the good of their members and the community at large.

As the experts tell us, COVID-19 puts people of old age and poor health at a more significant risk than those of the younger and healthier population. True to this, the statistics on deaths caused by the virus show that more people in these two categories make the higher numbers. That said, there is a need to offer specialized care and a show of support for these groups of people. For the sake of their health and lives, those who are sick need to take self-isolation and self-quarantine seriously. As Kanu points out, if the respect given to the elders has practical effect in the maintenance of custom and tradition, then we can also somewhat say, although with some reservation, that our national authorities and leaders (governments) by their directives and lockdown protocols seek the social good and welfare of all citizens. Thus, it is worth sacrificing a few of our luxury and freedoms to pay heed to their directives. It is within the ethics of Ubuntu to think beyond self-interest and consider the greater good of the community in all of one's actions.

Furthermore, although the elders of societies are highly regarded for their wisdom and experiences, they are also known to be physically weaker due to their age. It, therefore, call on the community to protect them since they are 
most at risk of dying from the virus. The ethics of Ubuntu require that those who are stronger and better off protect and provide for the weak and vulnerable in society. The idea of old people's home, which is prevalent in the West, is foreign in traditional Africa because old people are not considered in traditional African societies as a burden. It is more of a blessing to have an old person in one's home because they enforce good moral behavior among the young and the passing on of traditional values to the younger generations. At the same time, caring for older family members is a moral duty of the younger generation. This virtue of care embedded in the ethics of Ubuntu must be emphasized and brought to bear in this period of coronavirus.

\section{Conclusion}

Although changes in culture often occur slowly and sometimes even unintentionally, there are certain instances in history where certain events, episodes or happenings accelerate cultural change. The 2020 COVID-19 pandemic will pass as one of such occasions. Again, although it is evident that not every cultural value remains useful during this time, there are, within the same culture, some values that can be adopted in different ways to meet the new challenge. Thus, Gyekye (1995) was on point to have noted that the social, non-individualistic character of traditional African ethics, the traditional African conceptions of the value of man and the relationship between people in a society, and the sense of community and solidarity, and mutual responsibility are very needful in modern-day culture. They are, he noted, able to offer an adequate foundation for any social and ethical way of life today. The coronavirus pandemic provides a unique opportunity for Africans to revitalize these positive traditional values and demonstrate to the world the relevance, applicability, robustness, adaptiveness of African traditional cultural values.

Thus, the preoccupation of this chapter has been to highlight that the African ethics of Ubuntu contains in it such values or virtues that remain relevant and adaptive in times of the Coronavirus pandemic. These virtues include the show of solidarity and good human relationship, the strong regard for family and family values, and the elevated respect for authorities and elders. From these we postulate an ethic of care, brotherhood/sisterhood, social cohesion, and above all the pursuant of the community good or welfare. The chapter strongly holds that if the various virtues found within the ethics of Ubuntu are fully embraced, the African community can stand steadfastly in the fight against the COVID-19 pandemic.

\section{References}

Burke, Jason and Akinwotu, Emmanuel. 2020. Coronavirus could 'smoulder' in Africa for several years, WHO warns. Retrieved May 23, 2020 from https://www.theguardian. com/world/2020/may/08/coronavirus-could-smoulder-in-africa-for-severalyears-who-warns 
COVID-19 Coronavirus Pandemic. 2020. Retrieved May 5, 2020 from https://www. worldometers.info/coronavirus/?utm_campaign=homeAdUOA?Si

Eleojo, Fidelis Egbunu. 2014. Africans and African humanism: What prospects? American International Journal of Contemporary Research, 4(1), 297-308.

Gyekye, Kwame. 1995. An essay on African philosophical thought: The Akan conceptual scheme (Revised ed.). Philadelphia: Temple University Press.

Gyekye, Kwame. 1996. African cultural values: An Introduction. Accra: Sankofa Publishing Company.

Human Rights Watch. 2020. South Africa: End bias in Covid-19 food aid. Retrieved June 16, 2020 from https://www.hrw.org/news/2020/05/20/south-africa-end-biascovid-19-food-aid

Idang, Gabriel. E. 2015. African culture and values. Phronimon, 16(2), 97-111.

Iganus, Ruth Bulus and Haruna, Andrews. 2017. The strength of African culture in managing family crisis in a globalized world. Anthropology, 5(4), 1-5.

Igboin, Benson. O. 2013. Colonialism and African cultural values. African Journal of History and Culture, 3(6), 96-103.

Kanu, Macaulay A. 2010. The indispensability of the basic social values in African tradition: A philosophical appraisal. OGIRISI: A New Journal of African Studies, 7, 149-161.

Lassiter, James. E. 2000. African culture and personality: Bad social science, effective social activism, or a call to reinvent ethnology? African Studies Quarterly, 3(3), 1-21.

Magezi, Vhumani. 2018. Changing family patterns from rural to urban and living in the in-between: A public practical theological responsive ministerial approach in Africa. HTS Teologiese Studies/Theological Studies. Retrieved from http://www. scielo.org.za/pdf/hts/v74n1/42.pdf.

Mangena, Fainos. 2009. The search for an African feminist ethic: A Zimbabwean perspective. Journal of International Women's Studies 11(2), 18-30.

Metz, Thaddeus. 2007. Towards an African moral theory. The Journal of Political Philosophy, 15(3), 321-334.

Munyaka, Mluleki and Motlhabi, Motlhabi. 2009. Ubuntu and its socio-moral significance. In Felix Munyaradzi Murove (Eds.), African ethics: An anthology of comparative and applied ethics. Scottsville: University of KwaZulu-Natal Press, 63-84.

Nussbaum, Barbara. 2009. Reflections of a South African on our common humanity. In Felix. Munyaradzi Murove (Eds.), African ethics: An anthology of comparative and applied ethics. Scottsville: University of KwaZulu-Natal Press, 100-109.

Plan International. 2020. Millions trapped between hunger and covid-19 in Zimbabwe and Mozambique. Retrieved June 16, 2020 from https://plan-international.org/ news/2020-05-13-zimbabwe-and-mozambique-catastrophe-hunger-and-covid

Ramose, Mogobe. B. 2002. The philosophy of ubuntu and ubuntu as a philosophy. In P. H. Coetzee and A. P. J. Roux (Eds.), The African philosophy reader (2nd ed.). New York: Routledge, 230-238.

Ramose, Mogobe. B. 2009. Ecology through Ubuntu. In Felix Munyaradzi Murove (Eds.), African ethics: An anthology of comparative and applied ethics. Scottsville: University of KwaZulu-Natal Press, 308-314.

Sherer, Paul. M. 2020. Overcoming Covid-19 in South Africa: Direct relief donates $\$ 1$ million, serves as U.S. fiscal agent for solidarity fund. Retrieved June 16, 2020 from https://www.directrelief.org/2020/08/overcoming-covid-19-in-south-africa/ 
36 Beatrice Okyere-Manu and Stephen Nkansah Morgan

SPAR South Africa. 2020. SPAR South Africa and operation hunger donate 3,000 food parcels to families in need. Retrieved June 16, 2021 from https://spar-international. $\mathrm{com} /$ news/spar-south-africa-and-operation-hunger-donate-3000-food-parcelsto-families-in-need/

Wasserman, Helena and Moynihan, Qayyah. 2020. Bill Gates warned the coronavirus could hit Africa worse than China. Retrieved February 25, 2020, from https:// www.businessinsider.com/bill-gates-warns-coronavirus-could-hit-africa-withdire-consequences-2020-2? $\mathrm{IR}=\mathrm{T}$ 